Article Type: Research Paper

\title{
Does the High or Low of Corporate Social Responsibility Disclosure affect Tax Avoidance?
}

\author{
Firda Ayu Amalia ${ }^{1 *}$ and Eny Suprapti ${ }^{2}$
}

\begin{abstract}
:
Research aims: This research aimed to empirically prove the difference of the extent of Corporate Social Responsibility (CSR) disclosure towards tax avoidance. Design/Methodology/Approach: 38 companies listed in Indonesia Stock Exchange (IDX) in 2017 were selected through purposive sampling. The analysis methods used were the independent t-test and the SPSS version 24.

Research findings: The results showed that there was no difference between the companies with high CSR disclosures and those with the low ones towards tax avoidance. This indicates that despite the high and low disclosures, the companies' CSR disclosures generate the same impact towards tax avoidance. Theoretical contribution/ Originality: This research has a novelty in the form of a comparison of CSR disclosures by companies and their impact on tax avoidance. Practitioner/Policy implication: Furthermore, the practical contribution to the government, especially the Directorate General of Taxes, is that CSR disclosure is used by companies to gain legitimacy from the public, especially investors. CSR disclosure is not for window dressing to avoid tax.

Research limitation/Implication: The limitation in this study is the number of samples is less representative in representing the population. This is due to the small number of companies listed on the IDX in reporting and disclosing CSR in the sustainability report.
\end{abstract} AFFILIATION:

1, 2 Department of Accounting, Facult of Economics and Business, Universitas Muhammadiyah Malang, East Java, Indonesia.

*CORRESPONDENCE:

firdaayu@umm.ac.id

THIS ARTICLE IS AVAILABLE IN:

http://journal.umy.ac.id/index.php/ai

DOI: 10.18196/jai.2102149

CITATION:

Amalia, F. A. \& Suprapti, E. (2020) Does the High or Low of CSR Disclosure affect Tax Avoidance? Journal of Accounting and Investment, 21(2), 277-288.

Keywords: CSR Disclosure; High and Low Disclosure; Tax Avoidance

\section{ARTICLE HISTORY}

Received:

5 December 2019

Reviewed:

9 December 2019

3 Apr 2020

Revised:

29 January 2020

28 Apr 2020

Accepted:

8 May 2020

\section{Introduction}

Tax is the sector that gives the most significant contribution to Indonesia's income. Based on data from the 2018 State Budget (APBN), the state revenue contributed from tax is $79.82 \%$ (Kemenkeu, 2018). The income derived mostly from taxes is intended to improve the welfare of the community. One form is infrastructure development. It can be said that the tax paid by the community will benefit the community again (Mardlo, 2018). It fits for the community to fully support the government's efforts to optimize tax revenue, for example, not trying to avoid tax efforts.

Based on 2019 State Budget Draft data, the growth of tax in the last five years (2013-2017) has increased to 6.5\% (Kemenkeu, 2019). However, the increase was not offset by an increase in the tax ratio. The tax ratio is the ratio of tax revenue to the total Gross Domestic Product (GDP) (Malang). 
Indonesia's Tax Ratio from 2014 to 2017 continues to decline (Kemenkeu, 2019). This is a lousy indication because the tax ratio reflects a country's ability to finance its needs from the tax sector. Pakpahan (2019) explains the smaller the tax ratio, the more unable to finance its needs.

Unlike in previous years, the tax ratio in 2018 has increased. The tax ratio generated in 2018 was $11.6 \%$ or an increase of $0.9 \%$ compared to 2017 (Kemenkeu, 2019). However, the increase is also still relatively low. This is because the tax ratio figure is still below the average tax ratio of countries in Southeast Asia (Malang). The reason for the low tax ratio in Indonesia is the low level of tax compliance by taxpayers (Lubis, 2018).

As explained earlier, the low tax ratio in Indonesia, one of the causes is the low level of compliance. The tendency of taxpayers to try to avoid taxes. The same is true for companies. Lanis and Richardson (2013) explained that in the last twenty years, tax evasion actions by companies increased rapidly. This can be interpreted that tax is one component of the burden that can reduce corporate income (Dharma \& Noviari, 2017). The common thing done by companies is to avoid taxes.

Tax avoidance is legal because the method used is to exploit loopholes that are still contained in tax regulations (Ningrum, Suprapti, \& Anwar, 2018). Even though tax avoidance is a legal thing, but from an ethical perspective, tax avoidance is unethical. (Thomsen \& Watrin, 2018). Unethical because tax avoidance can reduce the amount of income that should be received by the state so that things that should be able to be done to improve the welfare of the community cannot be done optimally (Dharma \& Noviari, 2017; Whait, Christ, Ortas, \& Burritt, 2018).

Ethically whether or not the actions were taken by the company is very closely related to the theory of legitimacy. Legitimacy theory explains that every company always tries to maintain legitimacy or positive image in the community (Malang). Positive legitimacy from the community can make sustainability for a company. One of the ways to build positive legitimacy by companies is to carry out social responsibility, known as Corporate Social Responsibility (CSR) (Ningrum et al., 2018). Companies that try to build positive legitimacy by disclosing CSR activities that have been carried out tend to avoid tax avoidance (Lanis \& Richardson, 2013). As explained earlier, tax avoidance is legal but unethical. When a company implements CSR that aims to improve the welfare of society, the company is considered to have responsible, ethical-moral actions (Erawati, 2019). If the positive legitimacy of a company has been formed and on the other hand the company does something unethical, namely tax avoidance, then positive legitimacy can turn into legitimacy or a negative image of the community (Dharma \& Noviari, 2017). The company does not desire this.

Research on CSR disclosures and their effects on tax avoidance has been conducted by (Amalia, 2019; Hidayat, Ompusunggu, \& Suratno, 2018a; Malang; Ningrum et al., 2018; Wardani \& Purwaningrum, 2018). The results of these studies find evidence that CSR disclosure has a negative effect on tax avoidance. This shows that companies that disclose CSR will make companies reluctant to avoid tax. In line with the theory of 
legitimacy that the company seeks to maintain the positive legitimacy that has been formed.

Research conducted now has a novelty, first in the form of a comparison of CSR disclosure by companies and their impact on tax avoidance. In Indonesia, there have been many studies on the effect of CSR disclosure on tax avoidance. However, comparative research aimed at proving the existence of differences in the extent of CSR disclosure between companies when linked to tax avoidance is still little done. The referenced study used is research Fallan and Fallan (2019) and Lanis and Richardson (2013). The second novelty is the cultural and regulatory differences from the two previous studies. This is based on research suggestions conducted by (Fallan \& Fallan, 2019). Fallan and Fallan (2019) suggested that future researchers conduct similar studies but in different country contexts and cultural characteristics. This is intended to strengthen the theoretical contribution of research. The sample used in this study were all companies listed on the Indonesia Stock Exchange (IDX) in addition to the financial sector in 2017.

In Indonesia, there are no rules regarding how many companies must report CSR disclosure components (Addini, Cheisviyanny, \& Setiawan, 2019). While this is only a regulation that requires companies to report CSR activities that have been carried out, namely in the Act. No. 40 of 2007 article 66 paragraph 2c (Hidayat et al., 2018a). This situation becomes a gap because the results of previous studies found evidence that the level of disclosure of CSR can be an indication of whether or not tax avoidance by companies.

The theoretical contribution of this research is to provide evidence that there is no difference between companies with high and low CSR disclosure on tax avoidance. The results show that high or low CSR disclosure cannot be a tool to indicate tax avoidance by sample companies in Indonesia. This is possible because Indonesia is included in the state of civil law (Ratmono \& Sagala, 2015) so it has different cultural characteristics with the sample companies in previous studies (Fallan \& Fallan, 2019; Lanis \& Richardson, 2013). Furthermore, practical contributions to the government, especially the Directorate General of Taxes (DGT), are looking for other ways to be able to detect tax avoidance. It can be said that the way companies maintain legitimacy is not in the realm of taxation. The threat of legitimacy that might afflict the company does not appear to originate from tax avoidance (Anesa, Gillespie, Spee, \& Sadiq, 2019).

As explained earlier, the results of the study were different from previous studies allegedly due to differences in CSR and cultural regulations between Indonesia, Norway, and Australia. Besides, there are no standard rules for determining high and low CSR disclosures. They still use the author's justification. Based on these weaknesses, the researchers hope the results of research conducted now can be a motivation for the government to look for other ways that can be used to detect tax avoidance. This is intended to minimize the potential loss of state revenues from taxes. 


\section{Literature Review and Hypotheses Development}

\section{Legitimacy Theory and CSR}

The theory of legitimacy put forward by Dowling and Pfeffer (1975) explains about organizational legitimacy. An organization tries to build a match between social values related to the activities or activities of the organization and norms of behavior that are acceptable in the social system where they are. The match between social values and norms in a social system is called a social contract. Fulfillment of social contracts is intended so that the organization, in this case, the company can obtain legitimacy that has an impact on its survival (Lindawati \& Puspita, 2015).

Under the theory of legitimacy that the company will try to take action following community expectations (Lin, Cheng, \& Zhang, 2017). Whait et al. (2018) explain one way to act according to community expectations is to take ethical action in the form of disclosure of social responsibility (CSR) that has been done. Even if the company has acted according to the expectations of the community, but does not disclose it in CSR report, then the legitimacy of the company can be threatened (Lanis \& Richardson, 2013).

Disclosure of social responsibility or CSR is motivated by a shift in the goals of the company itself. Previously, the company's goal was to maximize value for shareholders, but for the last 50 years, these goals have changed (Whait et al., 2018). The company will not be able to maximize profits for shareholders if it ignores social responsibility (Fallan \& Fallan, 2019). It can be said that CSR disclosure is a tool to legitimize the company.

\section{CSR and Tax Avoidance}

In recent years the field that is often associated with CSR disclosure is tax aggressiveness, where tax aggressiveness is closely related to tax avoidance (Whait et al., 2018). Tax avoidance is different from tax evasion. Even though tax avoidance is a legal action, this action is considered unethical because it causes the state to lose the income that should be obtained (Thomsen \& Watrin, 2018).

Avoiding the loss of revenue that should be received by the state, CSR disclosure can be used as a parameter (Lanis \& Richardson, 2013). The parameter in question is the extent of CSR disclosure made by the company can be an indication of whether or not tax avoidance is done. Kiesewetter and Manthey (2017) explain that CSR disclosure can affect corporate tax avoidance behavior.

Research on CSR strategies to tax avoidance behavior has been carried out by (Fallan \& Fallan, 2019). Take a sample of companies in Norway listed on the Oslo stock exchange (OSE). CSR disclosures in Norway are divided into mandatory CSR disclosures and voluntary CSR disclosures. The results showed that there was a negative relationship between CSR disclosures that are mandatory with tax avoidance. Companies that are 
complete in reporting CSR disclosures that are mandatory tend to have little or no tax avoidance. Also, companies that disclose CSR elements that are mandatory also act according to tax regulations (Fallan \& Fallan, 2019). This study concludes that there are differences in influence on tax avoidance conducted between companies that disclose mandatory aspects of CSR and companies that disclose voluntary aspects of CSR.

Similar research was also carried out by Lanis and Richardson (2013). Compare 20 samples of companies in Australia that are included in the group of companies that are aggressive towards taxes according to the tax office and 20 companies that are not aggressive. CSR disclosure is associated with tax aggressiveness based on the theory of legitimacy. The results of the study prove that there are differences in CSR disclosures between companies that do and don't tax aggressiveness. Companies that do a lot of CSR disclosure tend to avoid tax. It can be logical that to keep its legitimacy, companies that carry out tax aggressiveness do a lot of CSR disclosures so that a positive image is saved in the community. Lin et al. (2017) states this is consistent with the theory of legitimacy. When there is a difference between corporate actions and community expectations, a company seeks to legitimize its relationship with the community by disclosing CSR.

In Indonesia, research on the effect of CSR disclosure on tax avoidance has been widely carried out (Dharma \& Noviari, 2017; Dwilopa, Bambang Jatmiko, \& Si, 2016; Maraya \& Yendrawati, 2016); Ningrum et al. (2018). Research conducted in Indonesia is associative research aimed at proving the effect of CSR disclosure on tax avoidance. Relatively little research has been aimed at comparing companies with high and low CSR disclosure on tax avoidance. The study proves that tax aggressiveness has increased rapidly since the last 20 years (Lanis \& Richardson, 2013). Tax aggressiveness, of course, violates the social and ethical aspects because it dramatically influences the government's ability to provide public goods.

Based on the results of research Fallan and Fallan (2019) conducted in Norway and Lanis and Richardson (2013) in Australia, similar studies should also be conducted in Indonesia. The purpose of this research is to prove whether there are differences between companies with high and low CSR disclosure on tax avoidance. This is because the results of the two studies stated that different CSR disclosures could be used to detect tax avoidance. While in Indonesia, there are only regulations regarding the obligation to disclose CSR, as stipulated in the Act. Limited company. The second part of article 66, paragraph 6 of the Law. No. 40 of 2007 concerning Limited Liability Companies states that in the annual reports made by each company, at least disclose various reports which include reports on the implementation of social and environmental responsibility (OJK, 2016).

Based on the explanation of the theory and some previous studies that have been explained before, the researchers hypothesize:

$\boldsymbol{H}_{1}:$ There is a difference between companies with high and low CSR disclosure on tax avoidance. 


\section{Research Method}

This type of research is a comparative study that compared companies that do high CSR disclosures with companies that do low CSR disclosures and their effects on tax avoidance. Is there a difference between companies with low CSR disclosure and high tax avoidance.

The sample used is companies listed on the IDX in 2017. The selection of companies listed on the IDX as a sample is because they want to get a general picture of the broad comparison of CSR disclosures of all companies going public in Indonesia.

Purposive sampling technique was used as a method for determining the number of samples. The following are the sampling criteria set by the first researcher, companies listed on the IDX 2017 in addition to the financial sector. Second, companies that issue 2017 sustainable reports using the GRI Standard or GRI 4.0 guidelines. Third, companies that include tax expense information and profit before tax in the 2017 financial statements. Based on the established sample criteria, the number of samples used in this study was 38 companies.

The type of data used is secondary data. The data source comes from the sustainability report to find out the number of CSR disclosures and the company's financial statements to determine tax avoidance.

Tax avoidance is an independent variable in this study. Tax avoidance is an action to minimize the tax burden by utilizing taxation loopholes (Inkiriwang, 2017). Penghindaran pajak dalam penelitian ini diproksikan dengan earning tax rate (ETR). Tax avoidance in this study is proxied by earning tax rate (ETR). Based on a review of tax research conducted (Hanlon \& Heitzman, 2010), ETR is a proxy used for tax avoidance. ETR can be calculated with the following formula:

$$
\mathrm{ETR}=\frac{\text { Tax Expense }}{\text { Income before Tax }}
$$

ETR values range from 0 to 1 . The smaller the ETR value, the higher the tax avoidance, and vice versa (Astuti \& Aryani, 2016).

In this study, disclosure of Corporate Social Responsibility (CSR) was an independent variable. CSR is a form of fulfilling social responsibility to stakeholders for business actions taken by the company so that the company's goals are not only profit-oriented but also on the environment (Hidayat, Ompusunggu, \& Suratno, 2018b). This study refers to the Global Reporting Index (GRI) Standard and GRI 4.0. When the company discloses the indicator, it is given a value of 1 , if not given a value of 0 (Ningrum et al., 2018). Next, all indicators disclosed are added up. Following is the formula for calculating the amount of CSR disclosure made by a company: 


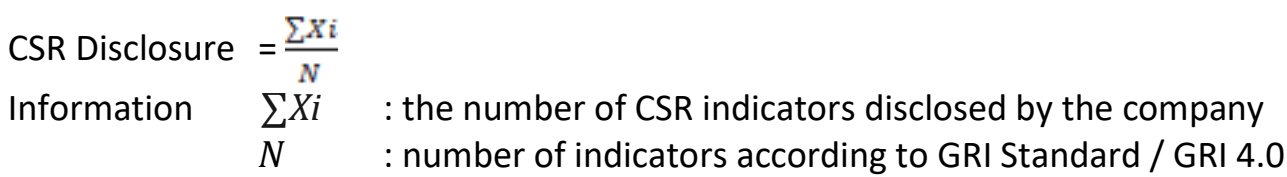

To determine the companies classified as high and low CSR disclosures, the researchers calculated the average number of CSR disclosures (the mean). The author sets the average as a cut off based on personal justification. This is due to the absence of government regulations regarding how many CSR disclosures companies must report. If a company has a CSR disclosure value above the average, then the company is classified as high CSR disclosure and given a value of 1 . However, if the amount of CSR disclosure is below average, then given a value of 0 .

The data analysis technique uses the t-test independent difference test with SPSS statistical tool version 24 . The reason for using the T-test independent difference test is the research data, including parametric statistics.

\section{Result and Discussion}

Before the discussion, the first thing the researcher did was to ensure that the data used were normally distributed. This was so that the results of the discussion are not biased. Based on the test results on 38 samples, it appeared that the data are normally distributed. This is proven by the residual significance value of 0.2 , which means that the value is $>0.05$. The residual significance value of 0.2 explained that there are differences between the study sample data. It has been proven that the data is normally distributed so that statistical testing can proceed. Next, Table 1 explained descriptive statistics.

The lower the value of ETR, the higher the tax avoidance carried out. On average, sample companies still take tax avoidance measures. An average ETR of $28.46 \%$ supports this. These results have the meaning of $100 \%$ profit before tax generated, the average amount of tax burden paid by the company is $28.46 \%$.

Companies in Indonesia, on average, make CSR disclosures of $47.3 \%$ of the total disclosure indicators according to GRI standards and GRI 4.0. It can also be said that CSR disclosure by companies in Indonesia is still not optimal. The average CSR disclosure of companies in Indonesia has not reached $50 \%$ of the total indicators. Both contained in the GRI Standard and GRI 4.0. It can be said that the company has only aborted obligations to report on its social responsibilities. However, the extent of the minimum disclosure, there are still no rules that require. The highest CSR disclosure is in PT. Asia Pulp, which is $67.46 \%$, during PT. PELNI made the lowest CSR disclosure, only $31.75 \%$.

Table 1 Descriptive Statistics

\begin{tabular}{lrrrr}
\hline Information & Highest Value & Lowest Value & Average & Standard Dev. \\
\hline Tax Avoidance (ETR) & 0.7789 & 0.0117 & 0.2846 & 0.1881 \\
CSR Disclosure & 0.6746 & 0.3175 & 0.472675 & 0.979278 \\
\hline
\end{tabular}


Does the High or Low of Corporate Social Responsibility Disclosure affect Tax Avoidance?

Table 2 Company Distribution

\begin{tabular}{llll}
\hline Information & Code & Number of Companies & CSR Disclosure Average \\
\hline CSR Disclosure & 1 & 16 & $49.05 \%$ \\
& 0 & 22 & $48.73 \%$ \\
\hline
\end{tabular}

Furthermore, researchers gave a value of 1 for companies that revealed CSR above average, and a value of 0 for companies that showed CSR below average. The following are the results of the distribution of companies that disclose CSR above average and below average.

Table 2 explains that more companies in Indonesia disclose below average CSR. The number of companies that disclose CSR above is only 16 companies. The rules regarding how many CSR components that must be disclosed do not yet exist. So researchers only use justification if the company discloses CSR above the average CSR disclosure in the sample company, then it is categorized as a company with high CSR disclosure.

The average disclosure of CSR in the high and low categories did not differ much. Based on Table 2 , it can be seen that the average CSR disclosure varies only by $0.32 \%$. It can be said that high and low CSR disclosures are relatively the same. Even companies with high CSR disclosure categories have not reached an average of 50\%. Researchers suspect that CSR disclosure is low because there are no rules regarding what components must be disclosed by each company.

Next, the researcher examines whether there are differences between companies with high CSR disclosure and companies with low CSR disclosure to tax avoidance. The researcher conducted a different test using the independent T-test different tests. Different test results showed a significance value higher than 0.05 , which is 0.604 . It can be concluded that there is no difference between companies that disclose CSR above average and companies that disclose CSR below average to tax avoidance. Both companies that disclose high or low CSR have the same effect on tax avoidance.

High or low CSR disclosure can be used to predict whether a company is doing tax avoidance. This is as explained by Fallan and Fallan (2019) and Lanis and Richardson (2013). Research conducted by Fallan and Fallan (2019) in Norway found that companies that only disclose mandatory aspects of CSR tend to have no tax avoidance measures. Conversely, companies that disclose more aspects of CSR that are voluntary tend to take more aggressive tax avoidance measures. This finding indicates that when a company avoids taxes but wants to keep the right image in society, the company does so by reporting more elements of CSR. Likewise, research conducted by Lanis and Richardson (2013) in Australia. The results of the study explained that companies that take more tax aggressiveness revealed the voluntary component of CSR.

However, the results of this study have different results from the two studies. This could be due to differences in the characteristics of the two studies with the research conducted now. Indonesia is included in the country code law, but Australia (Lanis \& Richardson, 2013) is a common law country (Ratmono \& Sagala, 2015). The results of 
previous studies (Fallan \& Fallan, 2019; Lanis \& Richardson, 2013) cannot be generalized in Indonesia.

Common law is a legal system that is sourced from generally accepted customs, not the written rules (laws) as in civil law (Aulia \& Al-Fatih, 2018). CSR is a corporate concept derived from common law (Riyanto, 2017). Furthermore, the adoption of the concept of CSR in Indonesia is regulated in a Limited Liability Company Law. Utama (2018) explained that the implementation of CSR in common law countries is more than just compliance with the law, but on the awareness of each company to protect the environment and build society. This is not in line with the implementation of CSR in Indonesia, which seems only to fulfill the company's obligations and maintain legitimacy (Marthin, Salinding, \& Akim, 2017).

Another reason that might explain why the hypothesis is not supported is the primary purpose of CSR disclosure by companies in Indonesia is to gain legitimacy from the public (Anesa et al., 2019; Marthin et al., 2017; Utama, 2018). This indicates that the legitimacy that companies are trying to maintain does not originate in the realm of taxation, but the public, especially investors in the capital market. This also shows that CSR disclosure is a form of company legitimacy to stakeholders to influence the investment decisions of stakeholders (Dewi \& Sanica, 2017; Sayekti, 2015). Lindawati and Puspita (2015) stated that the social and environmental consequences that exist for now and in the future had become one of the new consideration factors in investment decision making by investors in addition to financial factors.

\section{Conclusion}

This study aims to examine whether there are differences between companies that disclose high and low CSR on tax avoidance. Descriptive statistics show that the average sample company does tax avoidance. Also, the average company that discloses high CSR is less than companies that disclose low CSR. Statistical test results indicate that there is no difference in tax avoidance between companies that disclose high CSR and companies that disclose low CSR. The absence of differences in CSR disclosures in tax avoidance is suspected because CSR disclosures are used as a way to gain positive legitimacy from the public and investors. CSR disclosures are not used as window dressing for companies that avoid tax.

This study has limitations, namely the number of samples that are less representative in representing the population. This is due to the small number of companies listed on the IDX in reporting and disclosing CSR in the sustainability report. The research period is only one year, so the results of the research are less generalizable. This study was also only conducted for one year so that these results do not describe the phenomena in time series. Suggestions for further research are to research the same topic in different countries, preferably in countries included in civil law. This is because the research was currently taking samples in Indonesia, which includes code law, and the results show that the level of CSR disclosure did not affect tax avoidance. In contrast to previous 
studies that took samples in countries that are included in the common low. The results of the survey prove that differences in CSR disclosures can be a tool to detect whether or not companies take tax avoidance actions. Also, it is recommended to add years of observation to find more robust results.

\section{References}

Addini, N., Cheisviyanny, C., \& Setiawan, M. A. (2019). Analisis Pengungkapan Corporate Social Responsibility PT. Aneka Tambang Tbk Berdasarkan Global Reporting Initiatives (GRI) dan Kaitannya Terhadap Proper. Jurnal Eksplorasi Akuntansi, 1(3), 922-941. Received from http://jea.ppj.unp.ac.id/index.php/jea/article/view/118

Amalia, F. A. (2019). Pengungkapan Corporate Social Responsibility (CSR) dan Penghindaran Pajak: Kepemilikan Institusional Sebagai Variabel Moderasi. Jurnal Akuntansi dan Ekonomi, 4(2), 14-23. https://doi.org/10.29407/jae.v4i2.12719

Anesa, M., Gillespie, N., Spee, A. P., \& Sadiq, K. (2019). The legitimation of corporate tax minimization. Accounting, Organizations and Society, 75, 17-39. https://doi.org/10.1016/j.aos.2018.10.004

Astuti, T. P., \& Aryani, Y. A. (2016). Tren Penghindaran Pajak Perusahaan Manufaktur di Indonesia yang Terdaftar di BEI Tahun 2001-2014. Jurnal Akuntansi 20(3), 375-388. https://doi.org/10.24912/ja.v20i3.4

Aulia, F., \& Al-Fatih, S. (2018). Perbandingan Sistem Hukum Common Law, Civil Law dan Islamic Law Dalam Perspektif Sejarah dan Karakteristik Berpikir. Legality: Jurnal Ilmiah Hukum, 25(1), 98-113. https://doi.org/10.22219/jihl.v25i1.5993

Dewi, K. R. C., \& Sanica, I. G. (2017). Pengaruh Kepemilikan Institusional, Kepemilikan Manajerial, dan Pengungkapan Corporate Social Responsibility terhadap Nilai Perusahaan Pada Perusahaan Manufaktur yang Terdaftar di Bursa Efek Indonesia. Jurnal Ilmiah Akuntansi dan Bisnis, 2(1), 231-246. Retrieved from http://journal.undiknas.ac.id/index.php/akuntansi/article/view/175

Dharma, N. B. S., \& Noviari, N. (2017). Pengaruh Corporate Social Responsibility dan Capital Intensity Terhadap Tax avoidance. E-Jurnal Akuntansi 18(1), 529-556. Retrieved from https://ojs.unud.ac.id/index.php/Akuntansi/article/view/24562

Dowling, J., \& Pfeffer, J. (1975). Organizational legitimacy: Social values and organizational behavior. Pacific sociological review, 18(1), 122-136. https://doi.org/10.2307/1388226

Dwilopa, D. E., Bambang Jatmiko, S., \& Si, M. (2016). Pengaruh Corporate Social Responsibility, Capital Intensity, dan Perencanaan Pajak terhadap Penghindaran Pajak. Jurnal Universitas Muhammadiyah Yogyakarta, 1-15. Retrieved from http://repository.umy.ac.id/bitstream/handle/123456789/8328/NASKAH\%20PUB LIKASI.pdf?sequence $=1$

Erawati, A. F. E. (2019). Persoalan Hukum Seputar Tanggung Jawab Sosial dan Lingkungan Perseroan dalam Perundang-Undangan Ekonomi Indonesia. Article. Retrieved from http://ditjenpp.kemenkumham.go.id/hukum-pedata/847-persoalan-hukum-seputartanggung-jawab-sosial-dan-lingkungan-perseroan-dalam-perundang-undanganekonomi-indonesia.html

Fallan, E., \& Fallan, L. (2019). Corporate tax behaviour and environmental disclosure: Strategic trade-offs across elements of CSR? Scandinavian Journal of Management, 35(3). https://doi.org/10.1016/j.scaman.2019.02.001

Hanlon, M., \& Heitzman, S. (2010). A review of tax research. Journal of accounting and Economics, 50(2-3), 127-178. https://doi.org/10.1016/j.jacceco.2010.09.002 
Hidayat, K., Ompusunggu, A. P., \& Suratno, H. S. H. (2018a). Pengaruh corporate social responsibility terhadap agresivitas pajak dengan insentif pajak sebagai pemoderasi (Studi pada perusahaan pertambangan yang terdaftar di BEI). JLAFE (Jurnal Ilmiah Akuntansi Fakultas Ekonomi), 2(2), 39-58. https://doi.org/10.34204/jiafe.v2i2.543

Inkiriwang, K. G. (2017). Perspektif Hukum Terhadap Upaya Penghindaran Pajak Oleh Suatu Badan Usaha. Lex Et Societatis, 5(4), 13-18. Retrieved from https:// ejournal.unsrat.ac.id/index.php/lexetsocietatis/article/view/16072

Kemenkeu. (2018). APBN Kita Kinerja dan Fakta. Jakarta: Kementrian Keuangan. Article. Retrieved from https://www.kemenkeu.go.id/media/11284/apbn-kita-edisidesember-2018.pdf.

Kemenkeu. (2019). RAPBN 2019. Jakarta: Kementrian Keuangan. Article. Retrieved from https://www.kemenkeu.go.id/rapbn2019.

Kiesewetter, D., \& Manthey, J. (2017). Tax avoidance, value creation and CSR-a European perspective. Corporate Governance: The International Journal of Business in Society, 17(5), 803-821. https://doi.org/10.1108/cg-08-2016-0166

Lanis, R., \& Richardson, G. (2013). Corporate social responsibility and tax aggressiveness: a test of legitimacy theory. Accounting, Auditing \& Accountability Journal, 26(1), 75-100. https://doi.org/10.1108/09513571311285621

Lin, K. Z., Cheng, S., \& Zhang, F. (2017). Corporate Social Responsibility, Institutional Environments, and Tax Avoidance: Evidence from a Subnational Comparison in China. The International Journal of Accounting, 52(4), 303-318.

https://doi.org/10.1016/j.intacc.2017.11.002

Lindawati, A. S. L., \& Puspita, M. E. (2015). Corporate Social Responsibilty: Implikasi Stakeholder dan Legitimacy Gap dalam Peningkatan Kinerja Perusahaan. Jurnal Akuntansi Multiparadigma, 6(1), 157-174. https://doi.org/10.18202/jamal.2015.04.6013

Lubis, M. R. K. (2018). Memperbaiki Kinerja Tax Ratio: Sebuah Pendekatan Mikro. Article. Retrieved from http://www.pajak.go.id/article/memperbaiki-kinerja-tax-ratio-sebuahpendekatan-makro

Malang, F. A. A. U. M. Pengungkapan Corporate Social Responsibility (CSR) dan Penghindaran Pajak: Kepemilikan Institusional sebagai Variabel Moderasi. JAE (Jurnal Akuntansi dan Ekonomi), 4(2), 14-23. https://doi.org/10.29407/jae.v4i2.12719

Maraya, A. D., \& Yendrawati, R. (2016). Pengaruh corporate governance dan corporate social responsibility disclosure terhadap tax avoidance: studi empiris pada perusahaan tambang dan CPO. Jurnal Akuntansi dan Auditing Indonesia, 20(2), 147-159. https://doi.org/10.20885/jaai.vol20.iss2.art7

Mardlo, Z. A. (2018). Pajak untuk Pembangunan Infrastruktur Negeri. Article. Retrieved from http://www.pajak.go.id/article/pajak-untuk-pembangunan-infrastruktur-negeri

Marthin, Salinding, M. B., \& Akim, I. (2017). Implementasi Prinsip Corporate Social Responsibility (CSR) Berdasarkan Undang-Undang Nomor 40 Tahun 2007 Tentang Perseroan Terbatas. Journal of Private and Commercial Law, 1(1), 111-132. https://doi.org/10.15294/ipcl.v1i1.12358

Ningrum, A. K., Suprapti, E., \& Anwar, A. S. H. (2018). Pengaruh Pengungkapan Corporate Social Responsibility Terhadap Tax Avoidance dengan Gender Sebagai Variabel Moderasi (Studi Empiris pada Perusahaan Manufaktur yang Terdaftar di Bursa Efek Indonesia Tahun 2016). BALANCE: Economic, Business, Management and Accounting Journal, 15(01). 63-71. https://doi.org/10.30651/blc.v15i01.1260

OJK. (2016). Undang-Undang No. 40 Tahun 2007 Tentang Perseroan Terbatas. Jakarta: Otoritas Jasa Keuangan. Article. Retrieved from https://www.ojk.go.id/sustainablefinance/id/peraturan/undang-undang/Pages/Undang-Undang-No.-40-tahun-2007tentang-Perseroan-Terbatas.aspx. 
Pakpahan, R. (2019). Mengenal Rasio Pajak Indonesia. Article. Retrieved from https://www.kemenkeu.go.id/publikasi/berita/mengenal-rasio-pajak-indonesia/

Ratmono, D., \& Sagala, W. M. (2015). Pengungkapan corporate social responsibility (CSR) sebagai sarana legitimasi: dampaknya terhadap tingkat agresivitas pajak. Nominal, Barometer Riset Akuntansi dan Manajemen, 4(2), 16-30. https://doi.org/10.21831/nominal.v4i2.7997

Riyanto, A. (2017). Civil Law dan Common Law, Haruskah Didikotomikan? Article. Retrieved from https://business-law.binus.ac.id/2017/10/25/civil-law-dan-commonlaw-haruskah-didiikotomikan/

Sayekti, Y. (2015). Strategic Corporate Social Responsibility (CSR), Company Financial Performance, and Earning Response Coefficient: Empirical Evidence On Indonesian Listed Companies. Procedia-Social and Behavioral Sciences, 211, 411-420. https://doi.org/10.1016/i.sbspro.2015.11.054

Thomsen, M., \& Watrin, C. (2018). Tax avoidance over time: A comparison of European and US firms. Journal of International Accounting, Auditing and Taxation, 33, 40-63. https:// doi.org/10.1016/i.intaccaudtax.2018.11.002

Utama, A. S. (2018). Pelaksanaan Tanggung Jawab Sosial dan Lingkungan Perusahaan Berdasarkan Undang-Undang Nomor 40 Tahun 2007 untuk Meningkatkan Kesejahteraan Masyarakat Kecamatan Rumbai Pesisir Kota Pekanbaru. JCH Jurnal Cendekia Hukum), 4(1), 26-36. https://doi.org/10.33760/jch.v4i1.53

Wardani, D. K., \& Purwaningrum, R. (2018). Pengaruh Karakteristik Perusahaan dan Corporate Social Responsibility Terhadap Penghindaran Pajak. Jurnal Riset Akuntansi dan Keuangan, 14(1), 1-13. Retrieved from http://ejournalfb.ukdw.ac.id/index.php/jrak/article/view/294

Whait, R. B., Christ, K. L., Ortas, E., \& Burritt, R. L. (2018). What do we know about tax aggressiveness and corporate social responsibility? An integrative review. Journal of cleaner production, 204, 542-552. https://doi.org/10.1016/j.jclepro.2018.08.334 